p-ISSN 1693-9484, $e$-ISSN : 2621-8313

Majalah Ilmiah Bahari Jogja (MIBJ)

Vol. 19 No. 2, Juli 2021

(88-99)

DOI: $10.33489 /$ mibj.v19i2.266

(C) 2021 Sekolah Tinggi Maritim Yogyakarta

\title{
Pengaruh Public Speaking Pemimpin Terhadap Kinerja Awak Kapal
}

\author{
S.Teguh Wiyono ${ }^{1 *}$, Kuncowati Kuncowati ${ }^{2}$ \\ ${ }^{1,2}$ Universitas Hang Tuah, J1.Arif Rahman Hakim No.150 Surabaya \\ * Corresponding Author. E-mail : rogersts60@gmail.com Telp : 081330547914
}

\begin{abstract}
Abstrak
Kemampuan pemimpin (Nakhoda, Kepala Kamar Mesin, Perwira deck dan Perwira mesin) pada saat dinas jaga di kapal tidak hanya memerlukan pengetahuan dan skill tetapi juga berbagai teori, teknik, metode dalam public speaking sehingga mampu berbicara, menyampaikan pesan, informasi maupun perintah ke anak buah dalam regu kerja dinas jaga di kapal dengan baik sehingga komunikasi berjalan lancar dan menghilangkan kesalahpahaman supaya kinerja di kapal yang telah ditargetkan tercapai. Penelitian ini bertujuan untuk menganalis pengaruh public speaking pemimpin terhadap kinerja awak kapal. Penelitian ini menggunakan metode kuantitatif dengan analisis regresi linier dengan uji $-\mathrm{t}$. Respondent dalam penelitian ini adalah awak kapal niaga yang sedang berada di Pelabuhan Tanjung Perak Surabaya dengan jumlah 80 (delapan puluh) responden. Hasil dari penelitian berdasar regresi linier dan uji t adalah bahwa faktor public speaking pemimpin berpengaruh positif dan signifikan sebesar 0,610 satuan terhadap kinerja awak kapal dan berdasar uji determinasi diperoleh faktor public speaking pemimpin berpengaruh sebesar $37,1 \%$ terhadap kinerja awak kapal.
\end{abstract}

Kata Kunci: public speaking, pemimpin, kinerja.

\begin{abstract}
The ability of the leader ( Master, Head Of Engine Room, Deck Officer, Engine Officer) when watchkeeping on board requires not only knowledge, skills but also various theories, techiques, methods in public speaking so as to be able to speak, convey message, information and orders to the men in the guard work squad on board well so that communication runs smoothly and eliminates misunderstandings so that the performance on the ship that has been targeted is achieved. The Study aims to analisys the infuance of public speaking leaders on the performance of the crew. This study uses quanttative method with linear regression analisys with test-t. Respondent in this study is the crew of commercial ship that is in the Port of Tanjung Perak Surabaya with total Of 80 ( eighty) respondents. The result of this study based on linear regression and t test is that the public speaking faktor of the leader has a positive and significant effect of 0.610 units on the performance of the crew and based on the determination test obtained by the public speaking factor the leader affect $37.1 \%$ of the crew's performance.
\end{abstract}

Keywords: public speaking, leader, Performance 


\section{PENDAHULUAN}

Gaya kepemimpinan merupakan cara bagaimana pemimpin mempengaruhi bawahannya melalui cara - cara tertentu sehingga bawahannya dapat melaksanakan tugas dengan efektif dan efisien. Kepemimpinan adalah kemampuan untuk mempengaruhi, mengarahkan, memotivasi serta mengendalikan bawahannya dengan cara - cara tertentu sehingga bawahannya bisa menyelesaikan tugasnya secara efektif dan efisien. gaya kepemimpinan merupakan cara pemimpin mempengaruhi, mengarahkan, memotivasi, dan mengendaliakn bawahan dengan cara tertentu, sehingga bawahan dapat menyelesaikan tugas dengan efektif dan efisien (Siagian \& Khair, 2018).

Tren pengembangan kepemimpinan tidak hanya cukup belajar dan paham konsep kepemimpinan namun harus juga menguasai berbagai teknik atau tools soft-skill yang relevan, disesuaikan dengan posisi, situasi dan tantangan yang dihadapi perusahaan. Seorang pemimpin harus memiliki visi, dengan kekuatan kepemimpinan akan menghasilkan berbagai kebijakan dan operasionalisasi kerja yang dibimbing oleh visi pemimpin yang akan dijadikan dasar pencapaian tujuan organisasi. Namun yang terpenting adalah bagaimana mengkomunikasikan visi, misi dan tujuan organisasi dari pemimpin (selaku komunikator) kepada staf/ bawahannya (selaku komunikan) dengan baik dan benar demi tercapainya tujuan organisasi. Syarat utama terjadinya sebuah komunikasi adalah adanya interaksi antara para komunikator (penerima dan pemberi pesan). Selain menggunakan bahasa, gerak, isyarat, dan tanda, komunikasi juga dapat dilakukan dengan media lainnya. Era globalisasi saat ini, media komunikasi memberi kontribusi signifikan terhadap perubahan dunia. Komunikasi di abad kontemporer ini dapat dilakukan kapan saja dan dimana saja, tanpa hambatan ruang dan waktu.

Komunikasi merupakan suatu proses dimana seseorang memindahkan perangsang berupa lambang-lambang atau kata-kata untuk mempengaruhi tingkah laku orang lain, atau usaha untuk mengadakan persamaan pengertian/pendapat dengan orang lain. Terdapat 4 (empat) factor dalam proses komunikasi, yakni komunikator, berita, media komunikan (Audience, Decoder, Receiver. Kepemimpinan dan ketrampilan komunikasi atau public speaking , ibarat dua sisi mata uang yang saling melengkapi dan tidak dapat dipisahkan. Tanpa kemampuan public speaking, pesan, arahan, nasihat atau perintah pemimpin tidak mungkin tersampaikan (Hovland, 2007).

Komunikasi di kapal dilakukan baik dengan awak kapal, dengan kapal lain, serta dengan pihak - pihak yang terkait di pelabuhan. Media yang dipakai dapat berupa handy talky, VHF ( Very High Frequenty, telephon internal kapal, pengeras suara, maupun tanpa media komunikasi secara langsung saat breefing dan saat dinas jaga. Pada saat dinas jaga di kapal selain pengetahuan dan skill pemimpin kapal dalam mencapai tujuan organisasi di kapal kemampuan public speaking pemimpin di kapal ikut andil dalam tercapainya tujuan organisasi kapal karena public speaking pemimpin yang baik dapat mengurangi kesalahpahaman dalam berkomunikasi dan tersampaikannya suatu berita, pesan, perintah dengan baik dan memotivasi untuk melakukan pekerjaan, sehingga kinerja awak kapal 
meningkat. Oleh karena itu penelitian ini dilakukan bertujuan untuk menganalisis pengaruh faktor public speaking pemimpin terhadap kinerja awak kapal.

\section{KAJIAN LITERATUR}

Penelitian terdahulu bermanfaat untuk memperkaya teori, menambah kajian pustaka yang digunakan untuk mengkaji penelitian yang dilakukan. Pada penelitian ini yang dijadikan perbandingan tidak terlepas dari topik penelitian yaitu mengenai pengaruh public speaking pemimpin terhadap kinerja awak kapal. Perbandingan terhadap penelitian terdahulu terkait tema dalam penelitian ini dapat dilihat seperti berikut pada tabel 2.1 Perbandingan Penelitian Terdahulu :

Tabel 2.1 Perbandingan Penelitian Terdahulu

\begin{tabular}{|c|c|c|c|c|c|}
\hline No & $\begin{array}{l}\text { Nama Peneliti, } \\
\text { judul, tahun }\end{array}$ & Variabel & Metodologi & Hasil Analisa & $\begin{array}{c}\text { Persamaan } \\
\& \\
\text { Perbedaan } \\
\text { dengan } \\
\text { penelitian } \\
\text { sekarang }\end{array}$ \\
\hline 1 & $\begin{array}{l}\text { (Siahaan et al., } \\
\text { Pengaruh Gaya } \\
\text { kepemimpinan } \\
\text { dan Budaya } \\
\text { Kerja Terhadap } \\
\text { Kinerja Pegawai } \\
\text { di Kantor } \\
\text { Sekretariat } \\
\text { Komisi } \\
\text { Penyiaran } \\
\text { Indonesia Daerah } \\
\text { (KPID) provinsi } \\
\text { Kepulauan Riau, } \\
\text { 2014 }\end{array}$ & $\begin{array}{l}\text { Gaya } \\
\text { kepemimpinar } \\
\text {, Budaya } \\
\text { kerja, kinerja }\end{array}$ & $\begin{array}{l}\text { Kuantitatif } \\
\text { dengan } \\
\text { SPSS } 20\end{array}$ & $\begin{array}{l}\text { Gaya } \\
\text { kepemimpinan } \\
\text { berpengaruh } \\
\text { positif terhadap } \\
\text { kinerja dan } \\
\text { budaya kerja } \\
\text { berpengaruh } \\
\text { positif terhadap } \\
\text { kinerja }\end{array}$ & $\begin{array}{l}\text { Persamaan: } \\
\text { variabel } \\
\text { kinerja dan } \\
\text { budaya kerja } \\
\text { Perbedaan: } \\
\text { variabel } \\
\text { kepemimpina } \\
\text { n pada } \\
\text { penelitian ini } \\
\text { meneliti } \\
\text { publik } \\
\text { speaking. } \\
\text { Responden } \\
\text { pada } \\
\text { penelitian } \\
\text { sekarang } \\
\text { adalah awak } \\
\text { kapal }\end{array}$ \\
\hline 2 & $\begin{array}{l}\text { Citraningtyas, } \\
\text { Kepemimpinan } \\
\text { Transformasional } \\
\text {, Motivasi Dan } \\
\text { Disiplin Kerja } \\
\text { dan Pengaruhnya }\end{array}$ & $\begin{array}{l}\text { Kepemimpin } \\
\text { an, Motivasi, } \\
\text { disiplin } \\
\text { kerja. }\end{array}$ & $\begin{array}{l}\text { Analisis } \\
\text { regresi } \\
\text { linier } \\
\text { berganda } \\
\text { dengan } \\
\text { software }\end{array}$ & $\begin{array}{l}\text { Kepemimpinan } \\
\text { transformasional } \\
\text { dengan indikator } \\
\text { (reward, } \\
\text { punishment, } \\
\text { public speaking), }\end{array}$ & $\begin{array}{l}\text { Persamaan: } \\
\text { Variabel } \\
\text { kinerja, } \\
\text { metodologi }\end{array}$ \\
\hline
\end{tabular}




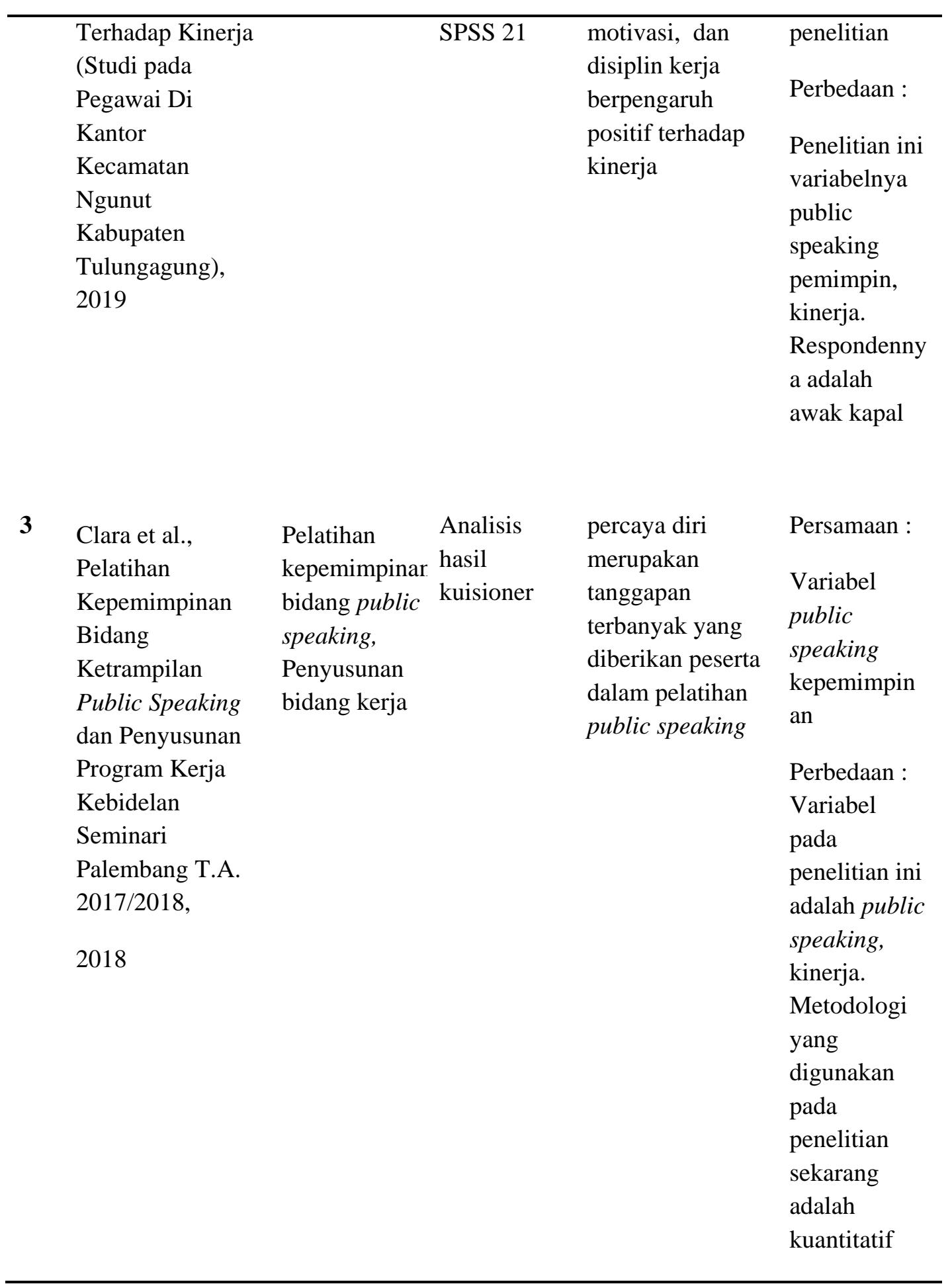

Sumber : Hasil kajian penulis, 2021

Berdasarkan Tabel 2.1 Perbandingan Penelitian terdahulu, dapat diketahui bahwa Menurut Siahaan et al. (2014) gaya kepemimpinan dan budaya kerja berpengaruh positif terhadap kinerja dan menurut Citraningtyas (2020) Variabel kepemimpinan dengan indikator reward, punishment dan public speaking 
berpengaruh positif terhadap kinerja. Dan menurut Clara et al. (2018) dari peserta pelatihan menyatakan bahwa public speaking sebagai penunjang kepemimpinan. Pada penelitian terdahulu yang dilakukan oleh Siahaan et al. (2014) respondennya pegawai di Kantor Sekretariat Komisi Penyiaran Indonesia Daerah (KPID) provinsi Kepulauan Riau dan variabelnya gaya kepemimpinan, budaya Kerja dan kinerja. Citraningtyas (2020) respondennya adalah Pegawai Di Kantor Kecamatan Ngunut Kabupaten Tulungagung dan variabelnya kepemimpinan transformasional, motivasi, disiplin kerja, kinerja. Berdasarkan penelitian terdahulu tersebut pada penelitian ini peneliti mengambil judul "pengaruh public speaking terhadap kinerja awak kapal", yang membedakan dengan penelitian terdahulu dengan penelitian ini adalah; (1) tempatnya, penelitian ini adalah di kapal, (2) respondennya adalah awak kapal , (3) Variabelnya adalah public speaking dalam kepemimpinan dan kinerja.

\section{PUBLIK SPEAKING}

Pada awal perkembangannya, public speaking sebagai bagian dari ilmu komunikasi, hanya berupa sebuah retorika. Komunikasi berasal dari Bahasa Latin : communis yang artinya "sama", kemudian berkembang menjadi communico, communico atau communicare, yang berarti menjadikan sama diantara satu dengan yang lainnya. Oleh karena itu, komunikasi menitikberatkan kepada kesamaan pemahaman diantara pembicara dan pendengar.

Menurut Echols \& Shadily (2003) Secara etimologi, kata public berasal dari bahasa Inggris yang berarti : Public "masyarakat umum" sedangkan speaking adalah berbicara atau berpidato. Menurut Julijanti \& Quraisyin (2012) istilah public speaking berawal dari para ahli retorika, yang mengartikan sama yaitu seni (keahlian) berbicara atau berpidato yang sudah berkembang sejak abad sebelum masehi. Sedangkan menurut Rakhmawati (2017) dalam sejarahnya yang panjang, istilah public speaking lebih dikenal dengan sebutan retorika atau dalam bahasa Inggris rhetoric bersumber dari bahasa Yunani rhet yang berarti orang terampil dan tangkas dalam berbicara. Pengertian retorika berkembang meliputi kemahiran melahirkan suatu gagasan, pandangan, pendapat, kelancaran berbicara, kepiawaian mempengaruhi orang banyak dengan kata-kata, daya kreasi dan improvisasi.

Griffin (2006) menjelaskan sebagaimana Aristoteles bahwa retorika adalah sebuah kemampuan seseorang dalam setiap fakta keadaan yang digunakan untuk mempengaruhi. Retorika sering digunakan untuk mengambil keputusan dalam argumen, debat legislatif, rapat politik, khotbah agama dan sambutan dalam perayaan special.

Menurut Burhanudin (2016) dilihat dari istilah bahasanya Public speaking merupakan hal yang baru, namun dalam kenyataan dan substansinya sama dengan retorika. Pada abad ke-20, retorika mengambil manfaat dari perkembangan ilmu pengetahuan modern, khususnya ilmu-ilmu perilaku seperti psikologi dan sosiologi. Istilah retorika mulai digeser speech communication, atau oral communication atau lebih dikenal dengan public speaking.

Wrenc (2012) menjelaskan bahwa public speaking adalah proses dari perancangan dan pengiriman sebuah pesan kepada audien. Public speaking yang 
efektif adalah melibatkan diri dengan pemahaman audien dan tujuan pembicaraan, memilih topik dasar yang sesuai dengan latar belakang audiens serta mampu mengirimkan pesan dengan terampil. Sedangkan Sirait (2007) seorang public speaker mendefinisikan public speaking sebagai seni yang menggabungkan semua ilmu dan kemampuan yang kita miliki. Lebih lanjut ia mengatakan bahwa memberanikan berbicara di depan umum artinya siap menyampaikan pesan kepada orang-orang yang latar belakangnya berbeda. Seorang pembicara publik harus bisa melakukan berbagai tugas sekaligus. Ia harus bisa menyampaikan informasi, menghibur, dan meyakinkan pendengarnya. Tanpa ilmu pengetahuan, informasi yang disampaikan bisa salah. Tanpa kemampuan mengingat cerita lucu dalam urutan yang betul, maka pembicara tidak akan bisa menghibur pendengar. Selanjutnya, tanpa kepercayaan diri, seorang pembicara tidak akan bisa meyakinkan orang lain untuk percaya. Intinya, public speaking yang baik dekat dengan kesuksesan.

Dapat disimpulkan bahwa public speaking dalam adalah kemampuan dalam berkomunikasi lisan baik berupa presentasi, ceramah, pidato atau jenis berbicara di depan umum lainnya untuk menyampaikan sebuah ide, gagasan, pikiran, dan perasaan secara runtut, sistematis, dan logis dengan tujuan memberikan sebuah informasi, mempengaruhi bahkan menghibur para audiens. Sesuai penelitian ini pada lingkup pekerjaan di atas kapal public speaking pemimpin di atas kapal adalah kemampuan pemimpin kerja di kapal dalam berkomunikasi baik lisan maupun presentasi, ceramah, pidato atau berbicara di depan awak kapal seperti pada waktu breafing, memberi tugas, menyampaikan informasi kepada anak buahnya.

Menurut Clara (2018) manfaat penting yang diperoleh dari pelatihan public speaking adalah percaya diri, tips, manfaat, praktek, penunjang kepemimpinan dan $m$ engatasi kelemahan. Dalam kegiaan public speaking, seorang pembicara akan bertemu dengan salah satu dari empat metode seperti yang diungkapkan Webster dalam bukunya "Intoduction to Public speaking." diantaranya: Pertama, dengan spontan (Impromptu), biasanya cara ini disampaikan tanpa persiapan. Untuk itu, pembicara harus mampu mengembangkan substansi, memahami seni dan teknik berbicara dengan baik. Di samping itu, tentu saja faktor kebiasaan dan latihan yang cukup membantu. Kedua, menggunakan teks (manuscript), untuk menghindari kekeliruan biasanya cara ini digunakan oleh seorang pejabat negara atau seorang ilmuwan demi keakuratan materinya ia harus menyiapkan naskah untuk menyampaikan hasil penemuanya. Ketiga, mengingat kata perkata (memorized), cara seperti ini mengandalkan kekuatan ingatan pembicara. Keempat, mengingat kata kunci, kata kunci atau frase biasanya sudah dirangkai dalam out-line dan disertai dengan bahan-bahan pendukungnya. Cara penyampaian ini dianggap paling baik karena dinilai paling fleksibel sehingga paling umum digunakan dalam dunia bisnis dan professional (Ibrahim, 2007).

\section{KINERJA}

Menurut Mangkunegara \& Prabu (2005) terdapat beberapa faktor yang mempengaruhi pencapaian kinerja seseorang salah satunya adalah faktor kemampuan dimana menurut HB (2006) kemampuan awak kapal terdiri dari 
kemampuan potensial, knowledge (pengetahuan ) dan skill ( ketrampilan ), dan ruang lingkup kinerja meliputi :

1. Quantity work

Yaitu jumlah kerja yang dilaksanakan dalam suatu periode waktu tertentu

2. Quality of work

Yaitu kualitas kerja yang diukur berdasarkan syarat syarat kesesuaian dan

kesiapannya

3. Job Knowledge

Yaitu luasnya pengetahuan mengenai pekerjaan dan ketrampilan

4. Creativeness

Yaitu keaslian gagasan meliputi gagasan yang dimunculkan dan tindakan untuk menyelesaikan persoalan - persoalan yang muncul.

Menurut Mathis dan Jackson (2006) indikator kinerja meliputi kualitas, kuantitas, keandalan dan kemampuan dalam bekerjasama. Sedangkan pengertian awak kapal menurut Undang Undang RI No.17 Tahun 2008 Tentang Pelayaran, tentang pelayaran adalah seluruh orang yang bekerja atau diperkerjakan oleh pemilik atau operator kapal dan disijikan dalam sijil awak kapal. Berati kinerja awak kapal merupakan kualitas kerja, kuantitas kerja, keluasan pengetahuan dan ketrampilan serta creativitas awak kapal sesuai tugasnya dalam sijil awak kapal.

\section{METODE PENELITIAN}

Pada penelitian ini metode yang digunakan adalah metode kuantitatif. Jawaban yang diperoleh dari responden diolah dan dianalisis dengan menggunakan alat bantu program komputer SPSS, Statistic 26,0. Analisis kuantitatif dilakukan untuk menggambarkan hubungan antara variabel, dalam penelitian dengan menggunakan perhitungan statistik, analisis yang digunakan adalah analisis regresi linier dimana sebelumnya dilakukan uji validitas dan reabilitas terhadap Qutioner. Respondent pada penelitian ini sebanyak 80 ( delapan puluh ) orang awak kapal di Pelabuhan Tanjung Perak Surabaya. Sampel pada penelitian diambil dengan menggunakan teknik sampling proportionate stratified random sampling, yaitu teknik yang digunakan bila populasi mempunyai unsur yang tidak homogen dan berstrata secara proporsional.

Validitas adalah seberapa jauh alat dapat mengukur hal atau subyek yang ingin diukur ( Iqbal Hasan, 2004 ). Reliabilitas memiliki sifat dapat dipercaya. Suatu alat ukur dikatakan memiliki reliabilitas apabila dipergunakan berkali - kali oleh peneliti yang sama atau oleh peneliti yang lain tetap akan memberikan hasil yang sama. Jadi reliabilitas adalah seberapa jauh konsistensi alat ukur untuk dapat memberikan hasil yang sama dalam mengukur hal atau subyek yang sama ( Iqbal Hasan, 2004 ). Suatu konstruksi quitioner dikatakan reliabel jika nilai ( $\alpha$ ) lebih besar dari 0,6.

\section{Variabel Penelitian}

Variabel di dalam penelitian ini terdiri dari faktor- faktor berhubungan dengan public speaking pemimpin dan kinerja awak kapal. Pengukuran variabel penelitian dilakukan dengan memberikan definisi - definisi operasional sebagai

Majalah Ilmiah Bahari Jogja | 94 | http://jurnal.amy.ac.id/index.php/MIBJ/ 
indikator penelitian dari masing - masing variabel untuk memudahkan peneliti dalam memilih kategori derajat tingkat penelitian yang sesuai dengan yang dirasakan responden. Pada penelitian ini variabel penelitiannya terdiri dari :

1. Variabel independent (bebas) yaitu public speaking pemimpin di kapal yaitu kemampuan pemimpin di kapal dalam berkomunikasi lisan baik berupa presentasi, ceramah, pidato atau cara berbicara di depan awak kapal lainnya untuk menyampaikan sebuah ide, gagasan, pikiran dan perasaan secara runtut, sistematis dan logis dengan tujuan memberikan sebuah informasi. Indikator - indikator faktor public speaking pemimpin di kapal pada penelitian ini meliputi :

a. Kemampuan pemimpin dalam menyampaikan ide/ gagasan

b. Kemampuan pemimpin menyampaikan pesan/ informasi kepada anak buah

c. Kemampuan pemimpin dalam mempengaruhi/ mengajak anak buah

d. Kemampuan pemimpin untuk menghibur anak buah.

2. Variabe Dependent ( tergantung) pada penelitian ini adalah kinerja awak kapal yang ditunjukkan dalam kuantitas, kualitas, luasnya pengetahuan mengenai pekerjaan dan ketrampilan serta kratifitas awak kapal dalam melakukan pekerjaan yang menjadi tujuan organisasi di kapal yang meliputi indikator - indikator kinerja berikut:
a. Pekerjaan navigasi
b. Kegiatan Operasional kapal
c. Kegiatan Bongkar muat
d. Pekerjaan permesinan kapal

\section{Analisis Regresi Linear}

Analisis ini digunakan untuk menganalisis pengaruh antara variabel independen $(\mathrm{X})$ yaitu public speaking pemimpin terhadap variabel dependen (Y) yaitu kinerja(Astriawati, 2016). Model penelitian yang digunakan pada penelitian ini :

$$
Y=a+b \cdot X
$$

Keterangan :

Y : Kinerja awak kapal

a : Konstanta

b : Koefisien regresi faktor penelitian

$\mathrm{X} \quad$ : Faktor public speaking

\section{Koefisien Determinasi ( $\mathbf{R}^{\mathbf{2}}$ )}

Digunakan untuk mengetahui besar sumbangan variabel independen ( $\mathrm{X}$ ) yaitu public speaking pemimpin terhadap variabel dependen ( $\mathrm{Y}$ ) yaitu kinerja awak kapal. Rumus yang digunakan : 


$$
\mathrm{R}^{2}=\mathrm{r}^{2} \mathrm{X} 100 \%
$$

Keterangan :

R : Koefisien korelasi berganda

$\mathrm{r} \quad$ : Koefisien korelasi parsial

\section{PEMBAHASAN}

\section{HASIL UJI VALIDITAS}

Hasil uji validitas dan reabilitas dari jawaban 80 ( delapan puluh) responden yang keseluruhannya $100 \%$ berjenis kelamin laki-laki berdasarkan pertanyaan - pertanyaan yang diajukan yang diolah dengan SPSS statistic versi 26 sebagai berikut pada tabel 4.1 Hasil Uji Validitas:

Tabel 4.1 Hasil Uji Validitas

\begin{tabular}{lccc}
\hline Variabel Penelitian & r hitung & r tabel & Kesimpulan \\
\hline Public Speaking pemimpin (X) & & & \\
Jawaban Responden: & & & \\
Kemampuan pemimpin dalam menyampaikan ide/ gagasan & 0,699 & 0,220 & Valid \\
Kemampuan pemimpin menyampaikan pesan/informasi kepada anak buah & 0,778 & 0,220 & Valid \\
Kemampuan pemimpin dalam mempengaruhi/ mengajak anak buah & 0,755 & 0,220 & Valid \\
Kemampuan pemimpin untuk menghibur anak buah. & 0,329 & 0,220 & Valid \\
Kinerja (Y) & & & \\
jawaban Responden: & & & \\
Pekerjaan navigasi & 0,815 & 0,220 & Valid \\
Kegiatan Operasional kapal & 0,738 & 0,220 & Valid \\
Kegiatan Bongkar muat & 0,723 & 0,220 & Valid \\
Pekerjaan permesinan kapal & 0,476 & 0,220 & Valid \\
\hline
\end{tabular}

Sumber : Data Primer yang diolah, 2021

Berdasarkan pada Tabel 4.1 Hasil Uji Validitas dapat dijelaskan bahwa jawaban dari pertanyaan - pertanyaan yang diajukan adalah valid karena seluruh jawaban responden yang terdiri dari 8 (delapan) item pertanyaan yang merupakan 
indikator public speaking pemimpin dan kinerja pada penelitian ini seluruhnya diperoleh $\mathrm{t}$ hitung $>\mathrm{t}$ tabel $(0,220)$.

\section{HASIL UJI REABILITAS}

Uji reabilitas digunakan untuk menguji kehandalan suatu alat pengukur untuk dapat digunakan dalam penelitian. Dari hasil olah data dengan menggunakan SPSS statistic versi 26 didapat koefisien reabilitas masing - masing indikator pada variabel- variabel penelitian ini andal atau realibel karena memiliki koefisien alpha lebih besar dari 0,60 yaitu nilai alpha variabel public speaking pemimpin 0,773 dan nilai alpha variabel kinerja sebesar 0,672.

\section{HASIL REGRESI LINIER}

Untuk mengetahui hubungan antara public speaking pemimpin dan kinerja awak kapal maka dilakukan analisis regresi linier yang hasilnya pengolahan data pada penelitian ini dapat dilihat pada tabel 4.2 Ringkasan Hasil Regresi Linier

Tabel 4.2 Ringkasan Hasil regresi linier

\begin{tabular}{lrrrl}
\hline Variabel & Koefisien & $\mathrm{t}$ - rasio & Prog - sig & Kesimpulan \\
\hline Konstan & 6,778 & 4,269 & 0,000 & Signifikan \\
Public Speaking Pemimpin & 0,610 & 6,789 & 0,000 & Signifikan \\
$\mathrm{R}^{2}$ & 0,371 & & &
\end{tabular}

Sumber : Data Primer yang diolah, 2021

Berdasarkan hasil regresi linier pada tabel 4.2 Ringkasan Hasil Regresi Linier dapat diperoleh suatu model persamaan sebagai berikut :

$$
\mathrm{Y}=6,778+0,610 \mathrm{X}
$$

Berdasarkan model persamaan itu dapat diketahui bahwa faktor public speaking pemimpin di kapal berpengaruh positif dan signifikan terhadap kinerja awak kapal sebesar 0,610 satuan, artinya semua indikator variabel public speaking yaitu (kemampuan menyampaikan ide/ gagasan, kemampuan pimpinan menyampaikan pesan,pemimpin di kapal, kemampuan pemimpin untuk mengajak anak buahnya, kemampuan pemimpin untuk menghibur anak buahnya) berpengaruh sebesar 0,610 satuan. Dan hasil perhitungan diperoleh nilai koefisien determinasi $\left(\mathrm{R}^{2}\right)$ sebesar 0,371 . Hal ini berarti $37,1 \%$ variasi variabel kinerja dipengaruhi oleh variabel public speaking pemimpin sedangkan sisanya 62,9\% diterangkan variabel lain diluar model persamaan.

\section{HASIL UJI HIPOTESIS ( Uji t )}


Uji Parsial ( Uji t) digunakan untuk menganalisis apakah ada pengaruh antara variabel bebas ( public speaking pemimpin) terhadap variabel tergantung pada penelitian ini yaitu kinerja awak kapal, yang mana hipotesi yang diajukan adalah sebagai berikut:

Ho: Tidak ada pengaruh yang positif dan signifikan antara public speaking pemimpin terhadap kinerja awak kapal

Ha: Ada pengaruh yang positif dan signifikan antara public speaking pemimpin terhadap kinerja awak kapal

Apabila $\mathrm{t}$ hitung $>\mathrm{t}$ tabel maka Ho ditolak, dan apabilat hitung $<\mathrm{t}$ tabel maka Ho diterima. Dengan tingkat alpha $(\alpha)=0,05$ dengan sejumlah responden 80 (delapan puluh) orang diperoleh $\mathrm{t}$ tabel 1,994, sedangkan berdasarkan tabel 4.2 Ringkasan Hasil Regresi Linier diperoleh t hitung variabel public speaking pemimpin sebesar 6,789 sehingga t hitung $(6,789)>t$ tabel $(1,994)$, dengan demikian Ho ditolak sehingga dapat diartikan bahwa variabel public speaking pemimpin (X) memiliki pengaruh yang signifikan terhadap kinerja awak kapal (Y).

\section{PENUTUP}

\section{Kesimpulan}

Berdasarkan hasil analisis dan pembahasan pada penelitian ini dapat disimpulkan bahwa berdasarkan hasil regresi linier public speaking berpengaruh positif dan signikan terhadap kinerja awak kapal sebesar 0,610 satuan. Demikian juga berdasarkan uji t public speaking pemimpin berpengaruh signifikan terhadap kinerja awak kapal. Public speaking berpengaruh positif dan signifikan sebesar $37,1 \%$. oleh karena itu pemimpin di kapal yang meliputi pemimpin tertinggi di atas kapal adalah nakhoda dan perwira deck dan mesin yang menjadi pemimpin pemimpin regu dinas jaga dalam kegiatan navigasi, bongkar muat, pengoperasian kapal dan kegiatan permesinan kapal niaga meningkatkan kemampuan public speaking untuk meningkatkan kinerja di kapal. Penelitian ini diharapkan dapat memberikan masukan kepada pihak managemen kapal dan pemimpin di kapal bahwa untuk mencapai kinerja yang lebih meningkat tidak hanya pengetahuan dan skill saja yang harus dimiliki tetapi kemampuan public speaking pemimpin juga mempengaruhi.

\section{DAFTAR PUSTAKA}

Astriawati, N. (2016). Penerapan Analisis Regresi Linier Berganda Untuk Menentukan Pengaruh Pelayanan Pendidikan Terhadap Efektifitas Belajar Taruna Di Akademi Maritim Yogyakarta. Majalah Ilmiah Bahari Jogja, 14(23), 22-37.

Burhanudin, A. M. (2016). Kemampuan Public Speaking Mahasiswa Jurusan KPI IAIN Syekh Nurjati: Problematika dan Solusinya. ORASI: Jurnal Dakwah Dan Komunikasi, 7(1). 
Citraningtyas, W. (2020). Kepemimpinan Transformasional, Motivasi Dan Disiplin Kerja dan Pengaruhnya Terhadap Kinerja (Studi pada Pegawai Di Kantor Kecamatan Ngunut Kabupaten Tulungagung). REVITALISASI: Jurnal Ilmu Manajemen, 8(1), 129-133.

Clara, C., Inharjanto, A., Ratnaningsih, P. W., Leovani, E., \& Irzawati, I. (2018). Pelatihan Kepemimpinan Bidang Ketrampilan Public Speaking dan Penyusunan Program Kerja Kebidelan Seminari Palembang TA 2017/2018. Proceeding of The URECOL, 227-237.

Echols, J. M., \& Shadily, H. (2003). Kamus Bahasa Inggris-Indonesia. Jakarta: PT. Gramedia Pustaka Indonesia.

Griffin, E. M. (2006). A first look at communication theory. McGraw-hill.

HB, S. (2006). Pengantar Manajemen. Jakarta: Bumi Aksara.

Hovland, C. L. (2007). Definisi komunikasi. PT. Raja Grafindo Persada: Jakarta.

Ibrahim, I. S. (2007). Kecerdasan Komunikasi seni berkomunikasi kepada publik. Bandung: Simbiosa.

Julijanti, D. M., \& Quraisyin, D. (2012). Buku Ajar Public speaking. Madura: Prodi Ilmu Komunikasi Fakultas Ilmu Sosial dan Ilmu Budaya ....

Mangkunegara, A. P., \& Prabu, A. (2005). Manajemen SDM Perusahaan. Bandung: PT Remaja Rosdakarya.

Rakhmawati, I. (2017). Keterkaitan Public speaking dalam Komunikasi Dakwah.

Siagian, T. S., \& Khair, H. (2018). Pengaruh Gaya Kepemimpinan Dan Lingkungan Kerja Terhadap Kinerja Karyawan Dengan Kepuasan Kerja Sebagai Variabel Intervening. Maneggio: Jurnal Ilmiah Magister Manajemen, 1(1), 59-70.

Siahaan, R., Tibrani, T., \& Nasution, A. P. (2014). Pengaruh Gaya Kepemimpinan Dan Budaya Kerja Terhadap Kinerja Pegawai Di Kantor Sekretariat Komisi Penyiaran Indonesia Daerah (KPID) Provinsi Kepulauan Riau. EQUILIBIRIA, 1(2).

Sirait, C. B. (2007). The power of public speaking: kiat sukses berbicara di depan publik. Gramedia Pustaka Utama.

Undang Undang RI No.17 Tahun 2008 tentang Pelayaran, (2008).

Wrenc, J. S. (2012). Public Speaking Practice and Ethics. Retrieved on October, 10, 2016. 